\title{
A PESQUISA DO PROCESSO TRADUTÓRIO: UM OLHAR SOBRE O PASSADO E PARA O FUTURO - UMA ENTREVISTA COM O PROF. DR. ARNT LYKKE JAKOBSEN
}

\author{
TRANSLATION PROCESS RESEARCH: LOOKING BACK AND \\ LOOKING FORWARD - AN INTERVIEW WITH PROF. DR. ARNT \\ LYKKE JAKOBSEN
}

\author{
Igor A. Lourenço DA SILVA ${ }^{1}$ \\ Tânia LIPARINI CAMPOS ${ }^{2}$
}

Tradução de: Júlio César de Sousa e AMARAL e Guilherme DELGADO³

\begin{abstract}
Prof. Dr. Arnt Lykke Jakobsen (Copenhagen Business School) in several ways has set the grounds to the development of what now is known as "Translation Process Research." In this interview, he provides some background of and perspectives to the field, as well as some information about the scholar himself.
\end{abstract}

Keywords: Translation Process Research. Translog. Interview.

In 1995 Prof. Dr. Arnt Lykke Jakobsen, from Copenhagen Business School (CBS), Denmark, developed together with Lasse Schou their first version of Translog. Such an initiative, aimed at logging translators' timestamped keystrokes (i.e., key logging) while performing translation tasks, opened
Resumo: O Prof. Dr. Arnt Lykke Jakobsen (Copenhagen Business School) em boa medida lançou as bases para o que hoje se denomina "Pesquisa do Processo Tradutório". Nesta entrevista, ele fornece um histórico e perspectivas da área, bem como informações sobre o próprio pesquisador.

Palavras-chave: Pesquisa do Processo Tradutório. Translog. Entrevista.

Em 1995, o Prof. Dr. Arnt Lykke Jakobsen, da Copenhagen Business School (CBS), Dinamarca, desenvolveu, junto com Lasse Schou, a primeira versão do Translog. Essa iniciativa, que permitiu o registro dos acionamentos de teclas com seus respectivos tempos (key logging) realizados por tradutores e tradutoras em tarefas tradutórias,

\footnotetext{
${ }^{1}$ Professor adjunto da Universidade Federal de Uberlândia. Tem mestrado e doutorado em Estudos Linguísticos, área de concentração Linguística Aplicada, com foco em Estudos da Tradução, pela Universidade Federal de Minas Gerais. Tradutor PT-EN/EN-PT/ES-PT e revisor desde 2005. E-mails: ials@ufu.br, ialsigor@gmail.com

2 Professora adjunta do Curso de Tradução da Universidade Federal da Paraíba (UFPB). Tem doutorado em Linguística Aplicada, com ênfase em Estudos da Tradução, pela Universidade Federal de Minas Gerais (UFMG). E-mail: tania@cchla.ufpb.br

3 Júlio César de Sousa e Amaral: Professor de inglês com certificado de proficiência da Universidade de Cambridge. Possui Bacharelado em Tradução pela Universidade Federal de Uberlândia (2017). Atua como tradutor freelance na área de tecnologia da informação. Guilherme Delgado: Tradutor do inglês. Possui Bacharelado em Tradução pela Universidade Federal da Paraíba (2017). Email: guilhermedelgaduh@ gmail.com. Tradução supervisionada por Prof. Dr. Igor Antonio Lourenço da Silva e Prof ${ }^{a}$. Dra ${ }^{a}$ Tânia Liparini Campos
} 
several research avenues to tap into the translation process. From Translog's first version to its most recent "descendant" Translog-II, which was developed by Prof. Dr. Michael Carl and integrates eye tracking, several progresses have been witnessed within Translation Process Research (TPR).

In an interview kindly granted through e-mail on July 22nd, 2016, Prof. Jakobsen provides an overview of TPR and his own work in and contribution to the field of research. Over the last 20 years, a lot has been learnt about the translation process, and much more is still to be explored so we can truly understand how a translator copes with a translation task or even with similar tasks, including revision and post-editing.

This is a first-hand interview in which Prof. Jakobsen provides us with a humble, albeit exciting and perceptive, account of his comprehensive and fundamental trajectory within TPR.

\section{PART I}

TRANSLATION PROCESS

RESEARCH (TPR):

AN OVERVIEW

Da Silva \& Liparini Campos (D\&L): How would you describe translation process descortinou uma série de possibilidades de pesquisa sobre o processo tradutório. Desde a primeira versão do Translog até o seu "descendente" mais recente, o Translog-II, que foi desenvolvido pelo Prof. Dr. Michael Carl (CBS) e incorpora o rastreamento ocular (eye tracking), inúmeros avanços foram observados no âmbito da Pesquisa do Processo Tradutório (PPT).

Em entrevista concedida por e-mail em 22 de julho de 2016, o Prof. Jakobsen nos oferece uma visão geral da PPT e da sua inserção e contribuição para o campo de pesquisa. São mais de 20 anos de história, em que muito já se aprendeu sobre o processo tradutório, mas ainda há muito a ser explorado para se compreender como o tradutor ou a tradutora lida com uma tarefa tradutória ou mesmo com tarefas afins, como a revisão e a pós-edição.

Trata-se de uma entrevista inédita, em que o Prof. Jakobsen nos apresenta, com muita humildade, entusiasmo e lucidez, um relato de sua extensa e fundamental trajetória no âmbito da PPT.

\section{PARTE I}

A PESQUISA DO

PROCESSO TRADUTÓRIO (PPT): UMA VISÃO GERAL

\author{
Da Silva \& Liparini Campos (D\&L): Como \\ o senhor descreveria a pesquisa do
}


research (TPR)? What are its objectives, materials and methods?

Jakobsen $(J)$ : I see translation process research (TPR) as the branch of translation studies whose main objective is to answer the question: By what observable processes and presumed mental processes do translators arrive at their translations? The observable processes I have in mind are the movements of a translator's hand and fingers as a target text is written and the movements of a translator's eyes across a source text and the emerging target text. Other observable processes are, e.g., the translator's use of external sources of information, gestures, facial expressions and potentially many other, e.g., physiological phenomena. The mental processes involved in translation cannot be directly observed, but we can make reliable inferences about these processes from accurately timed behavioural data. Mental processes are not limited to what has sometimes been referred to as the translation act itself, the hidden inaccessible switching operation that connects meaning across two languages. The mental processes TPR wishes to explore include source text comprehension processes, text production processes, how these processes are coordinated, how the purpose and situational context of a translation are assessed, and then of processo tradutório (PPT)? Quais são seus objetivos, materiais e métodos?

Jakobsen $(J)$ : Eu enxergo a pesquisa do processo tradutório (PPT) como uma subárea dos estudos da tradução que tem como principal finalidade responder à seguinte pergunta: quais são os processos, observáveis e supostamente mentais, que o tradutor utiliza para produzir uma tradução? Os processos observáveis aos quais me refiro são os movimentos das mãos e dedos do tradutor à medida que o texto-alvo é produzido, bem como os movimentos oculares ao longo do texto-fonte e do textoalvo. Há, ainda, outros processos observáveis, como, por exemplo, o uso de fontes externas de consulta, os gestos, as expressões faciais, assim como outros tantos com potencial para análise (e.g., os fenômenos fisiológicos). Embora os processos mentais envolvidos em uma tradução não sejam passíveis de observação direta, podemos fazer inferências confiáveis acerca deles a partir de dados comportamentais que foram cronometrados com precisão. Os processos cognitivos não se restringem àquilo que, em algumas ocasiões, se denomina de ato tradutório propriamente dito - essa operação oculta e inacessível de comutação que conecta significados entre duas línguas. Os processos mentais que a PPT se propõe a explorar abrangem os processos de 
course also all the problem-solving, decision-making, language-switching and meaning evaluation that goes on at the core of translation.

Because TPR works with technological equipment and has been methodologically inspired by experimental and cognitive psychology, it has been quite strongly lab-oriented and has followed a behavioral-cognitive experimental methodological paradigm. Our typical modus operandi at the Copenhagen Business School's CRITT centre has been to collect data from translators' keyboard activity and from their eye movements across the source and target texts displayed on a computer screen and then to infer what processes were involved from those data.

Keystrokes have been logged with the various versions of Translog we have developed since 1995, and eye movements have been recorded with the eye trackers we have been able to purchase since 2006 (Tobii T50, T60/T120 and Eyelink 1000). An eye tracker records eye movements compreensão de texto, os processos de produção textual, a maneira como eles são coordenados, a maneira como se avaliam a finalidade e o contexto situacional de uma tradução, bem como, obviamente, as resoluções de problemas, as tomadas de decisão, a comutação de línguas e a avaliação de significados presentes no âmago de uma tradução.

Como a PPT se utiliza de recursos tecnológicos e tem buscado inspiração metodológica na psicologia experimental e cognitiva, sua prática tem sido fortemente centrada em experimentos laboratoriais e adotado um paradigma metodológico de experimentação de aspectos cognitivos e comportamentais. O modus operandi padrão adotado no CRITT (Centre for Research and Innovation in Translation and Translation), da Copenhagen Business School, na Dinamarca, consiste em coletar dados das atividades do tradutor no teclado do computador e de seus movimentos oculares ao longo do texto-fonte e do texto-alvo exibidos na tela, para, então, inferir sobre os processos subjacentes a esses dados.

$\mathrm{O}$ registro de acionamentos de teclas e mouse vem sendo realizado por meio das muitas versões do programa Translog desenvolvidas desde 1995, ao passo que os movimentos oculares têm sido gravados com rastreadores oculares que conseguimos adquirir a partir de 2006 (Tobii T50, 
across a computer screen showing both the source text (ST) and the emerging target text (TT), and it also records pupil diameter and other parameters. The combination of data from the two activities, looking at the screen and typing at the keyboard, permits the researcher to study both the reading and writing processes $a$ translator engages in, as well as the way in which reading and writing activities are coordinated. By studying how these behavioral processes unfold, separately and in conjunction, TPR attempts to discover regularities from which inferences can be made about the operation of cognitive processes underlying translation, how they can be modelled, and how knowledge about these processes can be turned to good use pedagogically and technologically.

We have sometimes extended the methodological paradigm with concurrent verbal think-aloud data (TAPs), but more often with data from retrospective think aloud sessions, interviews and/or responses to questionnaires. In connection with the European Eye-to-IT project (2006-2009) we purchased simple EEG equipment, which we never used much, but at other research centres TPR is currently being conducted not just with keylogging
T60/T120 e Eyelink 1000). Um rastreador ocular registra o movimento dos olhos pela tela do computador durante a exibição do texto-fonte (TF) e do texto-alvo (TA) que vai sendo produzido. Além disso, também permite o registro do diâmetro da pupila e de outros parâmetros. Os dados combinados das duas atividades (i.e., o olhar sobre a tela e a digitação por meio do teclado) permitem ao pesquisador investigar os processos de leitura e escrita empregados pelo tradutor, bem como a maneira como essas atividades se coadunam. Ao estudar o desdobramento desses processos comportamentais, seja de forma isolada ou conjunta, a PPT tenta identificar padrões de regularidades que permitem fazer inferências sobre os processos cognitivos subjacentes à tradução, a forma como podem ser modelados e como os conhecimentos acerca desses processos podem ser bem aplicados em termos pedagógicos e tecnológicos.

Em algumas ocasiões, complementamos o paradigma metodológico com dados obtidos simultaneamente a partir dos protocolos de verbalização do pensamento em voz alta (do inglês, think-aloud protocols, ou TAP), embora venha sendo mais comum a utilização de informações geradas em sessões retrospectivas de verbalização do pensamento, em entrevistas e/ou por meio de questionários respondidos pelos 
and eye tracking, but also with fancy equipment for studying brain activity, like 64-point EEG, fNIR and fMRI. Where verbal data are available together with a recording of the translator's keystrokes and eye movements from the same translation event, or/and where data from neural activity in the brain are available, the researcher's analysis of instrumentrecorded data can be triangulated with analysis of the qualitative verbal data (or other instrument-recorded data) to strengthen assumptions and hypotheses about the cognitive processes involved in translation.

Regardless of which combination of data collection methods is used, the fundamental theoretical assumption on which TPR is based is that there is a mindbrain-behavior correlation, which makes it participantes. Em função do projeto Eye-toIT (2006-2009), financiado pela União Europeia, adquirimos um equipamento de eletroencefalografia simples, que acabamos não utilizando de forma recorrente. Em outros centros de pesquisa, no entanto, a PPT vem sendo realizada não apenas com o registro dos acionamentos de teclas e mouse e do rastreamento ocular, mas também por meio de equipamentos sofisticados, como os dispositivos de eletroencefalografia de 64 canais, de espectroscopia de infravermelho próximo funcional e de imagem por ressonância magnética funcional. Se, juntamente com o registro dos acionamentos de teclas e mouse e dos movimentos oculares realizados pelo tradutor durante uma mesma tarefa de tradução, também estiverem disponíveis os dados verbais e/ou os dados referentes à atividade neural, o pesquisador pode triangular a análise dos dados registrados por determinado(s) instrumento(s) com a análise qualitativa dos dados verbais (ou com os dados registrados por outro/s instrumento/s), a fim de reforçar as suposições e as hipóteses acerca dos processos cognitivos envolvidos na tradução.

Independentemente do conjunto de métodos utilizados para a coleta dos dados, a principal prerrogativa teórica por trás da PPT é que há uma correlação mente-cérebrocomportamento, a qual possibilita que os 
possible for researchers to make wellfounded, grounded assumptions about cognition from evidence in the body (brain or behavior), sometimes triangulated with introspective evidence. Hence the preferred label 'translation process research'. The assumption is that cognitive ('mental') activity in our minds has observable and measurable behavioral correlates, both in our brains and in our bodies (movements of our eyes and fingers), which can be recorded as user activity data (UAD), and from which we can make reliable inferences about the cognitive processes we assume they are correlates of. This links TPR with key assumptions in cognitive psychology and neuroscience, as well as psycholinguistics and neurolinguistics.

\section{D\&L: What makes TPR an appealing and} important area of research within

\section{translation studies?}

J: TPR is important because it investigates the behavioral and mental process by which a translation comes into existence. The combination of eye movements and keystrokes reveals the way the mind of a pesquisadores façam suposições coerentes e bem fundamentadas acerca da cognição com base em evidências no corpo humano (sejam elas cerebrais ou comportamentais), podendo, às vezes, triangulá-las com evidências introspectivas. Isso explica a preferência pelo termo "pesquisa do processo tradutório". Parte-se do pressuposto de que nossa atividade cognitiva ("mental") possui correlatos comportamentais, tanto em nossos cérebros como em nossos corpos (os movimentos dos olhos e dos dedos), passíveis de observação e mensuração mediante registro sob a forma de dados da atividade do usuário (do inglês, user activity data, ou UAD); e assume-se que é possível, a partir desses correlatos, fazer inferências aceitáveis acerca dos processos cognitivos com os quais acreditamos que se relacionam. Esse é o ponto que a PPT tem em comum com os preceitos da psicologia cognitiva e da ciência neurológica, assim como com a psicolinguística e a neurolinguística.

\section{D\&L: O que torna a PPT uma área de pesquisa atrativa e importante dentro dos Estudos da Tradução?}

J: A PPT é importante porque investiga os processos comportamentais e mentais por meio dos quais uma tradução ganha vida. A combinação dos movimentos oculares e dos acionamentos de teclas e mouse revela como 
human translator works both in the construction of meaning from a text and in construction the text of the translation. It shows how both processes follow a pattern of reiterated steps, much like knitting, as they are coordinated in translation.

I think the appeal of TPR lies in its use of interesting new technology in relatively controlled lab-like experimental setups. It lies in the perception of working objectively with instrument-recorded, quantitative data that can be subjected to statistical analysis and represented computationally in video (replays) and in illuminating graphs (e.g. progression graphs). And then it also lies in the fascination of the human mind, the amazing wonder of how we learn, remember, communicate and understandeven across different languages.

D\&L: Why and how was the program Translog developed? What kind of data does the program provide and how does it contribute to TPR? What are Translog's limitations? How did the program evolve from its first to its latest version (Translog 2006, and indirectly Translog-II)? opera a mente de um tradutor humano tanto para a construção de significados do textofonte quanto para a construção do texto-alvo. Mostra como ambos os processos de construção seguem um padrão, com estágios que se repetem, tal qual ocorre no caso do tricô, já que estão coadunados na tradução.

Em minha opinião, o que torna a PPT atraente é o fato de utilizar tecnologias novas e interessantes para realizar experimentos de forma relativamente controlada em ambientes semelhantes a laboratórios. Também é porque se tem a percepção de que se executa um trabalho objetivo, envolvendo o uso de dados quantitativos registrados por instrumentos e passíveis de análise estatística e de representação computacional por meio de vídeos (reproduções) e de gráficos ilustrativos (e.g., gráficos de progressão). Além disso, há o fascínio pela mente humana, incluindo a forma surpreendente como aprendemos, recordamos, nos comunicamos e compreendemos - até mesmo por meio de diferentes línguas.

D\&L: Como e por que o programa Translog foi desenvolvido? Que tipos de dados ele disponibiliza e como contribui para a PPT? Quais são as limitações do Translog? Como foi a evolução do programa desde a primeira versão até a 
J: The story of why Translog was developed is that after studying translations and comparing source texts with target texts, I had become interested in studying the thought process leading to the final version of a translation. I wanted to know, e.g., what interim solutions had been considered and how and why. As a teacher of translation, I was interested in knowing more about how my students arrived at the final solutions I saw so that I might help them better. This was not new. Since about 1980 many researchers and teachers had developed a similar interest, e.g. in tracing the steps taken in foreign language acquisition or in developing writing skills. The methodology on offer at the time was think-aloud protocolling, which I had tried to use a little, but was not comfortable with. I then got this idea (in 1995) that as translators were now mostly typing their translations on a keyboard, it would be possible to record or 'log' their entire typing process, noting what keystrokes were made and exactly when. By this simple method, I would have a full, objective record of the typing process, which I thought would be an interesting supplement to think-aloud data and possibly help me interpret such data by mais recente (o Translog $2006 \mathrm{e}$, de forma indireta, o Translog-II)?

$\mathrm{J}$ : O motivo que levou ao desenvolvimento do Translog foi que eu, após analisar traduções e comparar textos-fonte com textos-alvo, me interessei em investigar o processo mental que levava ao produto final de uma tradução. Meu desejo era saber, por exemplo, que soluções provisórias haviam sido consideradas, de que forma e por que razão. Como docente de tradução, meu interesse era saber mais sobre como meus alunos chegavam às soluções definitivas que eu recebia e, assim, poder ajudá-los com mais propriedade. Mas isso não era novidade alguma. Já na década de 1980, muitos pesquisadores e professores demonstraram o mesmo tipo de interesse a fim, por exemplo, de identificar os estágios envolvidos na aquisição de línguas estrangeiras ou no desenvolvimento das habilidades de escrita. $\mathrm{Na}$ época, a metodologia disponível consistia nos protocolos de verbalização do pensamento em voz alta, os quais eu tentei utilizar até certa medida, embora com ressalvas. Visto que a maior parte dos tradutores digitavam suas traduções utilizando um teclado de computador, eu tive então a ideia (em 1995) de que seria possível gravar ou fazer um registro de todo o processo de digitação, observando que teclas eram pressionadas e especificamente quando isso ocorria. Por meio desse simples método, 
triangulating qualitative and quantitative data.

Like many of my colleagues, I had taken courses in computer programming in the 1980s, but was very fortunate in having a son, Lasse Schou, who at the age of 15 was an enthusiastic Turbo Pascal 5.5 programmer and already in 1995 a far better programmer than I was. So towards the end of 1995 we jointly created the first DOS version of Translog. To begin with, it was created as two separate but related programs called Translog and Writelog. Translog (later to become Translog Supervisor) was the researcher's tool and was used to set up translation projects that could be used in Writelog (later Translog User). When Writelog displayed a project and a translator started typing a translation, it automatically recorded what keystrokes were struck and at what time. All the data recorded in Writelog were saved in a logfile, which the Translog component was designed to be able to access and either replay the typing process (at variable speed) or represent the data as one long string of characters, typos and all, eu teria um registro completo e objetivo do processo de digitação. Esse registro, a meu ver, seria interessante para complementar os dados provenientes dos protocolos de verbalização do pensamento em voz alta e poderia me ajudar a interpretar tais dados por meio da triangulação dos dados qualitativos e quantitativos.

Assim como muitos de meus colegas, eu havia feito cursos de programação na década de 1980, mas minha sorte mesmo foi ter um filho, Lasse Schou, que aos quinze anos programava em Turbo Pascal 5.5 por mero prazer e na época, em 1995, já era muito melhor que eu. Então, em fins de 1995 criamos conjuntamente a primeira versão em DOS do Translog. No início, foram criados dois programas independentes, porém relacionados, denominados Translog e Writelog. O Translog (que mais tarde se tornou o Translog Supervisor) funcionava como uma ferramenta de uso do pesquisador para configurar os projetos de tradução que poderiam ser abertos no Writelog (posteriormente transformado no Translog User). Quando o Writelog exibia um projeto e o tradutor começava a digitar sua tradução na interface disponibilizada, o programa automaticamente registrava que teclas eram utilizadas e em que momento. Todos os dados registrados pelo Writelog eram salvos em um arquivo legível pelo Translog, que, então, podia reproduzir o processo de 
interspersed with indications of the duration of time intervals between keystrokes.

My original aim was to create a program that would help me in my personal research, but both my colleagues and my students were immediately very interested, and feedback suggestions, especially from colleagues in the translation process research group TRAP, added new functions to the program. Students who had participated in early experiments were interested in the program for a different reason. They felt they gained useful knowledge from observing replays of their own performance and comparing them with replays of fellow students, performance. This opened up a pedagogical perspective that I had not anticipated.

Many slightly different versions of Translog were developed between 1995 and 1999. Lasse quickly corrected any little bugs we discovered and immediately implemented new ideas that came up. With the approach of the new millennium, we decided that the time had come to create digitação (com a possibilidade de variar a velocidade de reprodução) ou representar os dados sob a forma de uma longa sequência de caracteres (incluindo os erros de digitação e tudo mais que ocorresse na digitação), intercalados com indicativos do tempo de duração entre os acionamentos de teclas e mouse.

Meu objetivo inicial era criar um programa para auxiliar minha pesquisa. No entanto, tanto meus colegas quanto meus alunos demonstraram interesse imediato pelo programa; e as sugestões feitas após o terem utilizado, principalmente aquelas vindas de colegas que faziam parte do grupo TRAP, voltado para a pesquisa do processo tradutório, culminaram na implementação de novas funcionalidades. Já os alunos que participaram dos primeiros experimentos demonstraram interesse pelo programa por outra razão. Perceberam que estavam adquirindo novos conhecimentos ao observarem as reproduções do próprio desempenho e compará-las com as dos colegas. Isso criou uma perspectiva pedagógica que eu sequer havia previsto.

Entre 1995 e 1999, foram desenvolvidas muitas versões do Translog, porém com poucas diferenças substanciais entre elas. $\mathrm{O}$ Lasse rapidamente corrigia os poucos erros de programação que identificávamos e imediatamente implementava as novas ideias. Com a chegada do novo milênio, 
the first Windows version, called Translog 2000, for which Lasse used a programming language called Delphi 6. This version had a Translog Supervisor and Translog User module, and the entire graphic look of the program was changed. Translog 2000 remained the standard version until 2006 when participation in the EU FP6 project, Eye-to-IT, created an opportunity to radically update the program. In the project it was mandatory that Cyrillic script could be used and, most importantly, that it would be able to handle data from an eye tracker. Two new versions were planned, one that would update Translog, the key-logging program, and one more experimental that would be able to handle data from an eye tracker. Lasse, who had by then created his own IT company, completely revamped the key-logging program, this time programming in $\mathrm{C \#}$ and using the Microsoft .NET environment. He also created the content management system across which this version, labelled Translog 2006 Academic, was distributed. This version had the attractive and intuitive look of a professional Windows program and featured things like Unicode 8 and $X M L$. decidimos que era chegada a hora de criar a primeira versão para Windows, denominada de Translog 2000, para a qual o Lasse utilizou uma linguagem de programação chamada Delphi 6. Essa versão tinha os módulos Translog Supervisor e Translog User e contava com uma interface gráfica totalmente diferente da anterior. O Translog 2000 permaneceu como versão padrão até 2006, época em que a minha participação no projeto EU FP6, Eye-to-IT, criou as condições para que o programa passasse por uma atualização radical. O projeto exigia que fosse utilizado o alfabeto cirílico e, principalmente, que o programa trabalhasse com dados de rastreamento ocular. Foram planejadas duas novas versões, uma que atualizaria o Translog, o programa responsável pelo registro dos acionamentos de teclas e mouse, e outra de caráter mais experimental que trabalharia com dados de um rastreador ocular. O Lasse, que nessa época já havia fundado uma empresa de TI, modernizou todo o programa de registro de acionamentos de teclas e mouse, dessa vez utilizando a linguagem $\mathrm{C \#}$ e o ambiente de desenvolvimento .NET, da Microsoft. Ele também desenvolveu o sistema de gestão de conteúdo pelo qual foi distribuída essa versão, chamada Translog 2006 Academic. Essa versão trazia uma interface atraente e intuitiva, nos moldes de programas 
The experimental version developed specifically to meet the research targets of the Eye-to-IT project was the result of collaboration between a Russian programmer, Oleg Špakov, from the University of Tampere's computer science department, and Lasse. Between them they succeeded in creating a version that worked well enough for translation experiments to be run, but never well enough to be the dreamed-of Premium version of Translog. That is why this experimental version was never distributed, and it was left to Michael Carl, who joined the CRITT Centre late in 2008 to oversee the development of a Translog version with better and smoother integration of key and eye data. Since 2011 different versions of his revision of Translog, labelled Translog-II, have been distributed.

Translog, I believe, has helped produce more certain knowledge about how human translators read and make sense of texts, how they combine units of text to represent their meaning in text production, and at what level of meaning translation takes place. Translog has helped document the variation in the size of proprietários para Windows, além de dar suporte ao Unicode 8 e ao XML.

A versão experimental desenvolvida com o objetivo de atender às metas de pesquisa do projeto Eye-to-IT foi o resultado de uma parceria entre um programador russo, Oleg Špakov, do Departamento de Ciência da Computação da Universidade de Tampere (Finlândia), e o próprio Lasse. Eles conseguiram criar uma versão que funcionava bem para a realização de experimentos com tradução, mas não para os propósitos da tão sonhada versão "Premium" do Translog. Foi por esse motivo que essa versão nunca chegou a ser distribuída. Coube, então, a Michael Carl, que entrou no CRITT em fins de 2008, coordenar o desenvolvimento de uma versão do Translog que viabilizasse uma integração adequada entre dados de movimentos oculares e dados de acionamentos de teclas e mouse. A partir de 2011, passaram a ser distribuídas diferentes versões do Translog com base na revisão feita por Michael, intitulada Translog-II.

Acredito que o Translog vem ajudando a entender, de forma mais precisa, como o tradutor lê e compreende os textos, como combina as unidades de texto para representar o significado na produção textual e em que nível de significado ocorre a tradução. O Translog também vem ajudando a documentar a variação no 
processing units across individuals, depending particularly on different levels of language and translation expertise. More generally, it has proved to be a relevant tool for exploring human cognition.

There are of course obvious limitations to the program. It is a research instrument, not a translation tool, so it is different from the kind of program translators use in their everyday work, and it cannot log data from another program such as Word or Trados. This necessarily generates an element of artificiality in the experimental situation. Moreover, the program does not record all of the activity translators typically engage in as they translate, e.g. Internet search. It records whatever is inserted across the clipboard, but not what searches were made. For such information to be recorded, a screen recording device has to be run alongside Translog.

D\&L: What has TPR accomplished so far within translation studies? What are the challenges it has yet to face?

$J$ : Judging from the number of TPR publications in books, journals and PhD tamanho das unidades que os indivíduos processam, o que depende substancialmente dos diferentes níveis de proficiência linguística e tradutória. Em termos gerais, o Translog tem se revelado um programa relevante para se investigar a cognição humana.

O programa possui, naturalmente, suas limitações. Trata-se de um instrumento de pesquisa, e não de uma ferramenta de tradução, ou seja, ele é diferente do tipo de programa utilizado pelo tradutor em seu dia a dia e não registra dados provenientes de outros programas, como o Word ou o Trados. Isso é, inevitavelmente, um elemento de artificialidade no contexto experimental. Além disso, o programa não registra todas as atividades que o tradutor executa quando traduz (e.g., as pesquisas na internet). O programa registra as operações que usam a área de transferência, mas não informa as pesquisas efetivamente realizadas. Para que esse tipo de informação possa ser registrado, é preciso utilizar um dispositivo de captura de tela (screen recording) juntamente com o Translog.

D\&L: O que a PPT já conseguiu até o momento no âmbito dos Estudos da Tradução? Quais são os desafios que ainda terão de ser enfrentados?

$\mathrm{J}$ : A julgar pelo número de publicações envolvendo PPT em livros, periódicos, 
and MA theses and also the number of TPR papers given at conferences, I think it is reasonable to say that TPR has succeeded in establishing itself as a major research paradigm within Translation Studies. But translation is in transition and undergoing change, and therefore TPR also needs to change to be able to address emerging new forms of translation.

Translation is now nearly always done in some kind of interaction with technology. The majority of all industrial translation involves elements of postediting of machine-translated text. Fortunately, this is an area that TPR methodology is well suited to study. Eye tracking is a major technology for exploring the whole field of HumanComputer Interaction. From the point of view of the industry, increased productivity and efficiency are major objectives, and here insight from TPR about obstructive cognitive load or overload and factors that cause delay can be turned to good use. This is also the case if translation is looked at from the point of view of translators, who may be interested in increasing productivity if it leads to better remuneration, but will also be interested in more qualitative and emotional aspects of translating and in solutions that will dissertações de mestrado e teses de doutorado, e também pelo número de trabalhos na área apresentados em conferências, podemos dizer que a PPT conseguiu se estabelecer como um importante paradigma de pesquisa dentro dos estudos da tradução. Todavia, a tradução está em processo de mudança, de modo que a PPT também precisa mudar para ser capaz de lidar com novas formas emergentes de tradução.

Atualmente, a tradução é quase sempre realizada por meio de algum tipo de interação com a tecnologia. A maioria das traduções industriais envolve elementos de pós-edição de textos submetidos a tradução automática. Felizmente, essa é uma área para a qual a metodologia da PPT já se encontra adequada. $\mathrm{O}$ rastreamento ocular é uma das principais tecnologias para se investigar o campo da interação homem-máquina. Do ponto de vista da indústria, aumento de produtividade e eficiência são os principais objetivos - e, aqui, podem ser úteis contribuições da PPT sobre carga cognitiva obstrutiva ou sobrecarga e sobre fatores que causam retardos. Esse também é o caso se considerarmos a tradução sob o ponto de vista dos tradutores, que podem estar interessados não só em aumentar a produtividade caso tenha reflexos na remuneração, mas também em identificar aspectos mais qualitativos e emocionais da 
reduce stress and frustration and increase the ease and pleasure of translating. TPR methodology is also well suited to explore how some of such benefits can be achieved, but so far this perspective has hitherto not been explored extensively in TPR: the study of the effect of emotions and ergonomics on translation. TPR methodology could be used to do this, but would probably need to add new methods, possibly from psychology. If one wanted to study translation processes from the perspective of social psychology, which might be highly relevant as much translation involves extensive collaboration, TPR might play a role in such studies, although possibly a minor one. The challenge here is perhaps not to keep adding new technologies and instruments to TPR studies but to be aware of the contribution, scope and limits of TPR.

A major and perhaps rather monstrous challenge would be to develop a system that could be applied to the study of how translation is affected not only by cognition and activity in our brains, but by activity in the rest of our bodies, by tradução, bem como soluções que, por um lado, reduzam o estresse e a frustração e, por outro, aumentem a tranquilidade e o prazer de traduzir. A metodologia da PPT também é adequada para explorar a forma como alguns desses benefícios podem ser alcançados, mas, até agora esta perspectiva em específico não foi explorada extensivamente em PPT: o estudo do efeito das emoções e da ergonomia na tradução. A metodologia da PPT poderia ser usada para esse fim, mas provavelmente seria necessário adicionar novos métodos, provavelmente oriundos da psicologia. Além disso, em havendo interesse pelo estudo dos processos tradutórios sob uma perspectiva da psicologia social - o que pode ser altamente relevante, levando em conta o fato de que muitas traduções envolvem uma extensa colaboração -, a PPT também pode trazer contribuições, ainda que provavelmente desempenhando um papel secundário. O desafio aqui é, talvez, não continuar adicionando novas tecnologias e instrumentos para a pesquisa do processo tradutório, mas estar ciente da contribuição, alcance e limites da PPT.

Um desafio importante e, talvez, um tanto quanto gigantesco seria desenvolver um sistema que pudesse ser aplicado ao estudo de como a tradução é afetada não só pela cognição e atividade dos nossos cérebros, mas também pela atividade no 
emotions, and by translators' human and physical environments. This would be an application that would simultaneously collect text, key and gaze data, of course, but would also collect psychophysiological data from the translator (heart rate, respiratory rate, skin conductivity, blood sugar levels, hormonal activity, etc.), would collect reliable real-time data from neural activity, including hormonal and metabolic activity, and would collect all manner of relevant data (personal, social, ergonomic) about the environment. Such a system is probably not likely to ever be developed, although all of these lines of inquiry might be pursued separately. I also actually think there is virtue in simplicity and limitation, in restricting our focus to the study of what we see as the core of translation: the construction of meaning in a human translator's mind (and brain) from a source text and the coordinated production of a text in another language to represent that meaning or similar meaning, as has been the focus of TPR.

D\&L: In what ways can TPR contribute to translation learning and teaching? In particular, how can it contribute to modelling and eventually developing resto de nossos corpos, pelas emoções e pelos ambientes humano e físico dos tradutores. Seria uma aplicação que coletaria dados, simultaneamente, de texto, acionamentos de teclas e mouse e de movimentos oculares, é claro, mas também coletaria dados psicofisiológicos do tradutor (e.g., frequência cardíaca, frequência respiratória, condutividade da pele, níveis de açúcar no sangue e atividade hormonal), dados confiáveis, e em tempo real, da atividade neural e, inclusive, das atividades hormonal e metabólica, além de todos os tipos de dados relevantes (pessoais, sociais e ergonômicos) sobre o ambiente. Uma aplicação como essa, provavelmente, nunca será desenvolvida, embora todas essas linhas de pesquisa possam ser visadas separadamente. Na verdade, vejo como virtudes a simplicidade e a limitação em restringir o nosso foco para o estudo do que vemos como o núcleo da tradução: a construção de significados na mente (e cérebro) de um tradutor humano a partir de um texto-fonte em dada língua e a produção coadunada de um texto em outra língua para representar aquele significado ou um similar, como tem sido o foco da PPT.

D\&L: De que forma a PPT pode contribuir para o ensino e aprendizagem da tradução? Em particular, como pode contribuir para se modelar e, 
expertise? Moreover, how can it contribute to developing new tools for translators?

\section{J: I mentioned earlier that I was originally} surprised to find that translation students were interested in a program for learning purposes that I had developed to support my research interests. What students felt they could gain from having their text production process recorded was that watching the replay and remembering what had been on their mind, e.g. during a pause in production, increased their awareness of the kinds of challenge they faced when translating. This was even clearer when they were able to compare their own recordings with those of other students or professional translators. From the point of view of the teacher, the replay function made it possible to illustrate decision-making processes, show how a local decision might affect the whole phrase, collocation or clause of which the local item was a part, and discuss and compare the merits of alternative solutions and translation strategies. It has to be admitted, however, that for a teacher to have to look at the typing processes of maybe 30 students is a lot of work, and to my knowledge Translog has not been used much in a teaching context outside small translation classes, except for illustration.

consequentemente, se desenvolver
expertise? Além disso, como pode
contribuir para o desenvolvimento de
novas ferramentas para tradutores?

$\mathrm{J}$ : Como mencionei antes, fiquei surpreso ao descobrir que estudantes de tradução estavam interessados, para fins de aprendizagem, em um programa que eu tinha desenvolvido para atender aos meus interesses de pesquisa. Os alunos perceberam que poderiam se beneficiar da gravação do seu processo de produção textual, pois, ao assistirem à gravação e lembrarem o que tinha passado em suas mentes (e.g., durante uma pausa na produção), ganhavam mais consciência dos tipos de desafios que enfrentavam ao traduzir. Esse ponto ficava ainda mais claro quando eles comparavam as próprias gravações com as de outros estudantes ou tradutores profissionais. Do ponto de vista do docente, a função de reprodução da gravação tornou possível: ilustrar processos de tomada de decisão; mostrar como uma decisão em particular pode afetar todo o sintagma, colocação ou oração em que dado item está inserido; e discutir e comparar os méritos de soluções e estratégias de tradução alternativas. Há de se admitir, no entanto, que dá muito trabalho um professor observar os processos de digitação de, por exemplo, 30 alunos; e, pelo que sei, o Translog não tem sido muito utilizado fora de um contexto 
In the Eye-to-IT project we developed a gaze-based prompting system to assist translators. The system automatically popped up an interlinear translation suggestion whenever a translator's gaze had dwelled on a sourcetext word longer than the time we had defined as the maximum (250 ms). The assumption was that if a fixation exceeded the defined threshold, the translator was having a problem, however small, and would benefit from a suggestion. We presented the system in experiments both to translation students and to professional translators. The professional translators generally reported that they did not much like it, found it distracting, and felt they would do better and work faster without it. Students generally loved it and were able to translate much faster with the prompts than without them. We provided proof of concept, as was our ambition and promise, but have never since pursued the idea.

The main use of Translog as an instrument to help develop new translation tools, has been in the EU project CASMACAT (2011-2014), in which Michael Carl used his Translog II version de ensino com turmas pequenas de tradução, a não ser para fins de apresentação de exemplos.

No projeto Eye-to-IT, desenvolvemos um sistema de sugestões baseadas no olhar para auxiliar os tradutores. O sistema apresentava automaticamente uma sugestão interlinear de tradução sempre que o olhar de um tradutor se demorava em uma palavra do texto-fonte por mais tempo do que havíamos definido como limite (250 ms). Partimos do pressuposto de que, se a fixação excedesse o limite predefinido, o tradutor estava tendo um problema, ainda que pequeno, e se beneficiaria de uma sugestão. Apresentamos o sistema em experimentos, tanto para estudantes de tradução quanto para tradutores profissionais. Os tradutores profissionais geralmente se mostraram descontentes, pois o sistema os distraía, e sentiam que trabalhariam melhor e mais rápido sem ele. Os estudantes, por sua vez, geralmente adoravam e conseguiam traduzir muito mais rápido com as sugestões do que sem elas. Desenvolvemos uma prova de conceito, como havíamos ambicionado e prometido, mas nunca levamos a ideia adiante.

O principal uso do Translog como um instrumento para ajudar a desenvolver novas ferramentas de tradução ocorreu no âmbito do projeto CASMACAT, com financiamento da União Europeia (2011- 
to evaluate various graphic user interfaces for the CASMACAT post-editing environment that was developed in the project.

D\&L: What is your opinion regarding these two metaphors related to TPR: the borrowers, as suggested by O'Brien (2014), and the commonsensical notion of opening the black box as a metaphor for having access to the translator's mind?

\section{J: Polonius's advice to Laertes in Hamlet} is 'Neither a borrower nor a lender be', but what may be good advice in matters of personal economy does not seem to me to apply in the world of research and science. In the 1980s, perhaps unconsciously heeding Polonius's advice, much effort was made to establish Translation Studies as an autonomous discipline with its own methodology, but since then most T\&I research has indeed been a borrower and has happily adopted methods from such disciplines as cognitive psychology, psycholinguistics, sociology, cultural studies, and neuroscience. To my mind, such borrowing is perfectly OK (I borrowed the triangulation concept from
2014). No caso, Michael Carl usou a sua versão do Translog-II para avaliar diversas interfaces gráficas para o ambiente de pósedição do CASMACAT desenvolvido no projeto.

D\&L: Qual a sua opinião a respeito destas duas metáforas relacionadas à PPT: a ideia de que fazemos empréstimos de conceitos e métodos de outras áreas, conforme sugerido por O'Brien (2014) com o substantivo "borrowers", em inglês, e a noção do senso comum de que vamos "abrir a caixa-preta", ou seja, ter acesso à mente do tradutor?

J: Em Hamlet, Polônio aconselha Laertes: "Não empreste nem peça emprestado"4. Mas o que pode ser um bom conselho em matéria de economia pessoal não me parece se aplicar ao mundo da pesquisa e da ciência. $\mathrm{Na}$ década de 1980, talvez seguindo inconscientemente o conselho de Polônio, empreendeu-se muito esforço no intuito de estabelecer os estudos da tradução como um campo disciplinar autônomo, com metodologia própria. Entretanto, desde então, a maior parte das pesquisas em Tradução e Interpretação tem sido feliz em de fato tomar emprestados métodos de disciplinas como a psicologia cognitiva, a psicolinguística, a sociologia, os estudos culturais e a neurociência. A meu ver, esse

\footnotetext{
${ }^{4}$ SHAKESPEARE, William. Hamlet. Tradução de Millôr Fernandes. Porto Alegre: L\&PM, 2011.
} 
the social sciences) although it sometimes leads to terminological confusion. I also think it would be wonderful if Translation Studies could one day arrive at a level of disciplinary maturity to be a lender of methodologies to neighboring disciplines because TS had become a leader not only in the exploration of the operation of the bilingual brain and mind, but of the architecture and operation of the entire human language faculty.

What happens in the act of translation when meaning crosses over in the translator or interpreter's mind from being represented in one language to becoming represented in another is something we only know from its effect, when it suddenly emerges and presents itself in front of us. How the match is made, how much computation of how many features is done, is still largely a mystery to us. So we say it happens in a black box. The research dream, however, is to get to know what happens inside, which is different from knowing what goes on in the brain. Neuroscience is currently, figuratively speaking, taking the lid off the brain and looking deeper and deeper inside, but when it comes to the mind, we can only hope to find out about this by, again figuratively, empréstimo é perfeitamente válido (eu peguei emprestado o conceito de triangulação das ciências sociais), embora, por vezes, leve a confusões terminológicas. Também acho que seria maravilhoso se os estudos da tradução pudessem, um dia, chegar a um nível de maturidade disciplinar que lhe permitisse emprestar metodologias a outras áreas, porque os estudos da tradução se tornaram líder não apenas na investigação de como a mente e o cérebro bilíngue funcionam, mas também da arquitetura e funcionamento de toda a faculdade humana da linguagem.

O que acontece no ato de tradução quando o significado transita, na mente do tradutor ou do intérprete, da sua representação em uma língua para a sua representação em outra - é algo que só sabemos a partir de seu efeito, quando o resultado do processo emerge de repente e se apresenta diante de nós. Como a correspondência é feita, quanto cálculo de $n$ aspectos é feito, ainda é, em grande parte, um mistério para nós. Assim, dizemos que há uma caixa-preta. O sonho de todo pesquisador da área, no entanto, é saber o que acontece lá dentro, o que é diferente de saber o que se passa no cérebro. Atualmente, a neurociência tem retirado o tampo do cérebro - figurativamente falando - e observado cada vez mais fundo o que há lá dentro, mas, quando se trata da mente, nossa 
knocking on the outside of the box, i.e. by observing behavioral effects and exploring the brain. In Macbeth Shakespeare had King Duncan say, sadly: 'There's no art to find the mind's construction in the face', and nevertheless this is precisely what we are trying to do in TPR when we study eye movements and pupils as 'windows to the soul'. We are looking for the mind's construction in behavior. The black box metaphor is a helpful reminder of the need to distinguish clearly between the black box of the mind and the increasingly open brain.

PART II

THE RESEARCHER

WITHIN THE FIELD

D\&L: Could you tell us what led you to TPR?

J: The idea of TPR grew gradually out of the invention of Translog and was associated with a series of encounters with people who shared my interest in processoriented research. At a conference at $U A B$ in Barcelona in 1998, I met Candace Séguinot, one of the pioneers of processoriented translation studies, members of única esperança é descobrir alguma coisa batendo - em sentido figurado, mais uma vez - do lado de fora da caixa, ou seja, observando efeitos comportamentais e explorando o cérebro. Em Macbeth, de Shakespeare, o Rei Duncan diz, com tristeza: “Arte não há de descobrir na face o que vai dentro d'alma"s. No entanto, é justamente isso o que estamos tentando fazer na PPT quando estudamos os movimentos dos olhos e das pupilas como se fossem as “janelas da alma”. Nós buscamos acesso à mente pelo comportamento. A metáfora da caixa-preta é um lembrete útil da necessidade de se fazer uma distinção clara entre a mente, dentro de uma caixa-preta, e o cérebro, cada vez mais exposto.

\section{PARTE II}

\section{O PESQUISADOR EM RELAÇÃO AO CAMPO DE PESQUISA}

\section{D\&L: Poderia nos dizer o que o levou à PPT?}

J: A ideia da PPT cresceu gradualmente a partir da invenção do Translog e esteve associada a uma série de encontros com pessoas que compartilhavam do meu interesse por pesquisas orientadas para o processo. Em uma conferência na Universidade Autônoma de Barcelona (UAB), Em Barcelona (Espanha), em 1998,

\footnotetext{
${ }^{5}$ SHAKESPEARE, William. Macbeth. Tradução de Manuel Bandeira. São Paulo: Cosac Naify, 2009.
} 
the PACTE group, and Fabio Alves, all of whose work was helpful in formulating my version of TPR. In 1998, at a conference at Manchester University, I was approached by Antin Fougner Rydning from the University of Oslo, who was then preparing to rally a large number of European translation scholars interested in translation process studies (Sonia Tirkkonen-Condit, Riitta Jääskeläinen, Birgitta Englund-Dimitrova, Paul Kussmaul, Marianne Lederer and several others, including myself) around a European research project application, tentatively on the topic of translation expertise.

In 2002, during a research stay at the University of Stanford, I had meetings with Karl-Anders Ericsson, the originator of the think-aloud method, and had a chance to discuss research results with him, which Translog had helped me get, and which went against his central idea that information available in verbal form in short-term memory could be vocalized in think aloud sessions without interference from or by the ongoing processes. My data, which were subsequently published in conheci Candace Séguinot - uma das pioneiras nos estudos da tradução orientados para o processo -, membros do grupo PACTE (Procés d'Adquisició de la Competència Traductora i Avaluació) e Fabio Alves, todos eles com trabalhos que me foram de grande ajuda na formulação da minha versão da PPT. Em 1998, em uma conferência na Universidade de Manchester (Reino Unido), fui abordado por Antin Fougner Rydning, da Universidade de Oslo (Noruega), que pretendia congregar um grande número de estudiosos europeus interessados nos estudos processuais da tradução (Sonia Tirkkonen-Condit, Riitta Jääskeläinen, Birgitta Englund-Dimitrova, Paul Kussmaul, Marianne Lederer e vários outros, incluindo a minha pessoa) para a elaboração de um projeto de pesquisa europeu que trataria, possivelmente, da expertise em tradução.

Em 2002, durante uma minha estada como pesquisador visitante na Universidade de Stanford (Estados Unidos), me encontrei algumas vezes com Karl-Anders Ericsson, o criador do método de verbalização do pensamento em voz alta. Tive, então, a oportunidade de discutir com ele resultados de pesquisas que haviam sido obtidos com o aporte do Translog e que iam contra sua ideia central de que a informação disponível na forma verbal na memória de curto prazo poderia ser, em sessões de verbalização do 
Fabio Alves's Triangulating Translation in 2003, suggested that think aloud did lead to a degradation of the size of processing units. For this reason, the method of eliciting user data from participants was later to be mainly through cued, immediate retrospection, i.e. through participants' spoken comments as they watched a replay of their typing and eye movements in sessions immediately following a translation task.

Also in 2002, at an EU ICT event in Copenhagen, an accidental meeting with Kari-Jouko Räihä, a Finnish eye-tracking expert, convinced me that Translog would become a much stronger tool if it could be made to handle data from an eye tracker so that Translog would yield far more direct data especially about comprehension processes. This chance meeting subsequently led to close cooperation in the Eye-to-IT project.

To me, the combination of KEY and EYE and optional immediate cued retrospection was the methodological start of mature TPR. It was strictly empirical, pensamento, vocalizada sem a interferência dos/nos processos em curso. Meus dados, que foram posteriormente publicados no livro Triangulating Translation, editado por Fabio Alves, em 2003, apontavam que a verbalização leva a uma degradação do tamanho das unidades de processamento. Por essa razão, o método de coleta dos dados dos participantes veio, mais tarde, a se basear principalmente na retrospecção imediata, com os participantes tecendo comentários verbais enquanto assistiam a uma reprodução dos seus movimentos oculares e/ou acionamentos de teclas e mouse em sessões imediatamente posteriores a uma tarefa de tradução.

Ainda em 2002, em um evento europeu sobre tecnologias de informação e comunicação, em Copenhague (Dinamarca), encontrei-me, por acaso, com Kari-Jouko Räihä, especialista finlandês em rastreamento ocular, que me convenceu de que o Translog se tornaria uma ferramenta muito melhor se passasse a integrar dados de rastreamento ocular, de modo a fornecer dados muito mais diretos, especialmente sobre os processos de compreensão. Esse encontro casual nos levou a uma estreita cooperação no projeto Eye-to-IT.

Para mim, a combinação TECLA, OLHO e verbalização retrospectiva imediata auxiliada por reproduções do processo foi o início do amadurecimento metodológico da 
experimental and behavioral, but always aiming at making inferences about cognition. The vague theory on which TPR was based was an assumption that the micro-behavior our instruments recorded would allow us to make inferences about processing activity of a cognitively more primitive - and therefore more fundamental - kind than that obtained through higher-level linguistic analysis. Any claim we or others made about translation would have to be based on observable, experimentally welldocumented, replicable patterns found in low-level data.
PPT. Era algo estritamente empírico, experimental e comportamental, mas sempre com o objetivo de fazer inferências sobre a cognição. A vaga teoria sobre a qual a PPT se baseia se sustenta no pressuposto de que os microcomportamentos gravados por nossos instrumentos nos permitiriam fazer inferências sobre atividades de processamento de um tipo cognitivamente mais primitivo - e, portanto, mais básico que aquele obtido por meio de análises linguísticas de níveis mais macros. Qualquer afirmação sobre tradução feita por nós, ou por quaisquer outras pessoas, teria que ser baseada em padrões observáveis, experimentalmente bem documentados e passíveis de replicação encontrados em dados do nível micro.

\section{D\&L: Como o senhor resumiria o seu trabalho no âmbito da PPT?}

J: Olhando para trás, sinto que não fiz tanta pesquisa em PPT quanto gostaria. Durante muito tempo, estive mais envolvido com a instrumentalização do que com a pesquisa propriamente dita, embora as duas atividades estivessem sempre intimamente ligadas. Aconteceu de eu criar o Translog e, junto com o meu filho, me esforçar muito em melhorá-lo para acomodar as necessidades de colegas de pesquisa e em ajudá-los com o uso do programa, mas talvez eu pudesse ter passado mais tempo fazendo PPT. De toda 
TPR methodology that evolved around it, I think, helped at least part of our discipline become more solidly empirical. We were able to exactly define and visually document different translational behavior in three phases (initial orientation, drafting, and end revision). Translog helped us problematize the central claim of think aloud theory. It also helped in establishing a positive correlation between the size of processing units and translational expertise. And when eye tracking had been added, we were able to document the way in which reading purpose and translation task type influence gaze behavior. Some of these findings were as much the result of work done by my CRITT associates, especially Barbara Dragsted and Kristian T. Hvelplund, both of whom were my PhD students, and later Michael Carl and Laura W. Balling, whose strong backgrounds in computational linguistics, psycholinguistics and statistics added importantly to TPR developments and results after about 2009. forma, o Translog e a metodologia da PPT que evoluiu a partir dele, creio eu, ajudou pelo menos uma parte do nosso campo disciplinar a tornar-se mais fortemente empírica. Conseguimos delimitar exatamente, e documentar visualmente, diferentes comportamentos tradutórios em três fases (i.e., orientação inicial, redação e revisão final). O Translog nos permitiu problematizar as bases da teoria sobre a verbalização do pensamento em voz alta. Permitiu, também, estabelecer uma correlação positiva entre o tamanho das unidades de processamento e a expertise em tradução. Com a introdução do rastreamento ocular, conseguimos documentar a maneira como o propósito da leitura e o tipo de tarefa de tradução influenciam o comportamento do olhar. Alguns desses resultados vieram do trabalho realizado por membros associados ao CRITT, especialmente Barbara Dragsted e Kristian T. Hvelplund, ambos então meus doutorandos, e mais tarde Michael Carl e Laura W. Balling, cujos conhecimentos em linguística computacional, psicolinguística e estatísticas trouxeram importantes contribuições para o desenvolvimento da PPT e seus resultados após 2009, mais ou menos.

D\&L: Como o senhor avalia sua contribuição para a PPT? Na sua
D\&L: How do you assess your contribution to TPR? In what ways do you 
see you have set the ground for research in the area?

\section{J: This is for others to assess. My own view} is that my invention of Translog was a piece of historical luck. Translation process studies developed very strongly from about the middle of the 1980s with the work of Hans P. Krings and many others who were asking very similar questions and formulating very similar research goals. I see TPR as a continuation of this tradition, but with some important technical and methodological adjustments. With Translog, reading and typing time could be measured far more accurately than with methods used in the 1980s. Also, in Translog the reading and writing processes could be visualized and endlessly repeated in fast or slow replay, which made it possible to make observations at a much finer level of granularity than before. In this respect Translog has been somewhat like a microscope for observing processes.

D\&L: How do you feel about having so many researchers worldwide developing their work drawing on your seminal avaliação, de que formas as suas ações criaram as condições necessárias para o desenvolvimento das pesquisas na área?

$\mathrm{J}$ : Esse tipo de avaliação cabe às pessoas. Eu sinto que ter inventado o Translog foi um golpe de sorte que ficou na história. Os estudos sobre o processo tradutório estavam se desenvolvendo com muita rapidez desde meados da década de 1980, com o trabalho de Hans P. Krings e de outras tantas pessoas que faziam os mesmos questionamentos e formulavam as mesmas perguntas de pesquisa. Vejo a PPT como uma continuação dessa tradição, que agora passou por alguns ajustes técnicos e metodológicos importantes. O Translog possibilitou que o tempo de leitura e de digitação fossem mensurados com muito mais precisão do que se conseguia com os métodos utilizados na década de 1980. Também foi possível usar o Translog para visualizar os processos de leitura e de escrita e reproduzir as gravações, em modo rápido ou lento, quantas vezes fosse necessário, o que permitiu fazer observações com um nível de refinamento muito maior do que antes. Nesse sentido, é como se o Translog fosse um microscópio para observar processos.

D\&L: Como se sente sabendo que tantos pesquisadores no mundo desenvolvem seus trabalhos com base nos artigos, métodos e conceitos seminais que o senhor 
papers, methods and concepts regarding the translation process?

J: I feel enormously privileged, honored and thankful, also for the present initiative and effort by Tânia and Igor. I feel privileged and thankful not just for what contribution I may have made to translation process research but for the wonderful colleagues and students I have been able to share my interest with and for having had the opportunity to make a living out of trying to better understand the communicative wonder that has the potential to unite all humanity translation.

\section{introduziu às investigações sobre o processo tradutório?}

J: Sinto-me extremamente privilegiado, honrado e agradecido, inclusive por esta iniciativa da parte de Tânia e Igor. Sinto-me privilegiado e grato não apenas pela contribuição que possa ter feito para a pesquisa do processo tradutório, mas também pelos colegas e alunos formidáveis com os quais pude compartilhar meus interesses e por ter podido viver financeiramente deste trabalho que busca compreender melhor esta maravilha comunicativa que traz em si o potencial de unir toda a humanidade: a tradução. 